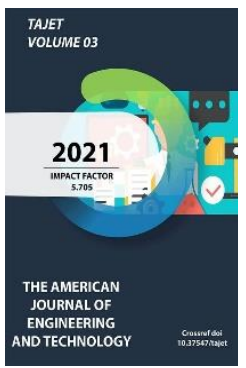

Copyright: Original content from this work may be used under the terms of the creative commons attributes 4.0 licence.

\section{Calculation Of The Required Capacity Of The Solar Collector In The Combined Heating System Of Buildings, Selection Of The Model And Evaluation Of Cost-Effectiveness}

\section{D.Sobirova}

Assistant, The Department Of Production Of Building Materials, Items And Structures, Fergana Polytechnic Institute, Fergana Uzbekistan

M.Karimova

Assistant, The Department Of Production Of Building Materials, Items And Structures, Fergana Polytechnic Institute, Fergana Uzbekistan

A. Gulomov

Student, Fergana Polytechnic Institute, Fergana Uzbekistan

\title{
ABSTRACT
}

The article calculates the thermal energy required for the correct choice of a heat pump and solar collector, which is part of a combined heating system, and the choice of their type and quantity based on the calculations performed and the profitability of water-based solar collectors, which are part of combined heating systems.

\section{KEYWORDS}

Solar collector, special selective coating, heat loss, combined heating system.

\section{INTRODUCTION}

It is known that on open days on each square meter of the surface of the solar collector falls 600-1200 kW of solar thermal energy, depending on the time of year, it is possible to receive an average of $900 \mathrm{~kW}$. The solar collector has a surface of $2 \mathrm{~m}^{2}$, covered with a special coating and has a heat absorption coefficient of $0.95 \%$. The back of the collector is covered with $5 \mathrm{~cm}$ thick mineral wool, the 
thermal conductivity of mineral wool is 0.035 $(\mathrm{W} / \mathrm{m}) * O C$.

If the temperature difference between the surface and the back of the collector is $50^{\circ} \mathrm{C}$, the amount of energy lost per 1 square meter is $(0,035 / 0,05) * 50=35 \mathrm{~W}$.

About the same amount of energy is lost on the sides, pipes and other parts of the collector. Covering the collector with a special selective coating, due to the correct choice of the distance between the glass and the heatabsorbing surface, heat radiation and air convection are minimal $[1,2,3]$.

With this in mind, we assume heat losses in a single collector of $100 \mathrm{~W}$.

Also, the atmosphere is not always transparent, the collector surface is not always ideally clean, where even if we assume that the heat loss is $100 \mathrm{~W}$, it can be assumed that 700 $\mathrm{W} / \mathrm{m}^{2}$ of heat is transferred from the collector surface.

The heat capacity of water is $4200 \mathrm{Dj} / \mathrm{kg}{ }^{* 0} \mathrm{C}$, the relationship between the units of power: 1 $\mathrm{W} *$ hour $=3600$ Joules, i.e. $1.16 \mathrm{~W}$ is needed to heat $1 \mathrm{~kg}$ of water to $1^{\circ} \mathrm{C}$. Based on these sizes, it is possible to deduce the conditional power magnitude for a solar collector with an area of $2 \mathrm{~m}^{2}-\mathrm{Q}_{\mathrm{k}}=2{ }^{*} 700 / 1,16=1206,9 \mathrm{~W}$. For its convenience, $\mathrm{Qk}=1200 / \mathrm{kg}$ *grad. can be accepted as. It should be noted that this number 1200 is appropriate when the water temperature is $10-70^{\circ} \mathrm{C}$.

Officially, this ratio shows how many kilograms of water can be heated by a solar collector at one degree per hour. That is, in addition to the natural temperature, the collector heats the temperature of 100 litres of water per hour to $12{ }^{\circ} \mathrm{C}$, and the temperature of 25 litres of water to $48{ }^{\circ} \mathrm{C}$. Based on the calculations, we choose the solar collector Thermotech FP202: total area $2.02 \mathrm{~m}^{2}$, adsorber area $1.84 \mathrm{~m}^{2}$, volume $1.56 \mathrm{I}$, maximum working pressure 10 bar, stagnation temperature $234{ }^{\circ} \mathrm{C}$, project flow $0.25-0.51 / \mathrm{min}^{*} \mathrm{~m}^{2}$, forced circulation in the collector electric drive power $50 \mathrm{~W}$. We calculate how many collectors are needed to heat the building, each with a surface area of $2 \mathrm{~m}^{2}$. To do this, we use the amount of power required to heat the building:

$$
Q_{m н}=V^{*} T^{*} K, \text { kcal / hour }
$$

Where $\mathrm{V}$ is the volume of heated rooms, $\mathrm{m}^{3}$;

$T$ is the difference between outside air and indoor air temperature, ${ }^{\circ} \mathrm{C}$;

K - coefficient of propagation (type of construction depends on the insulation condition of the room);

The value of the coefficient $K$ is selected as follows:

- For simplified wooden structures or corrugated metal sheets, in the absence of thermal insulation $\mathrm{K}=3.0-4.0$;

- For a brick wall, $K=2,0-2,9$ when the thermal insulation is partial;

- For a standard wall with a thickness of two bricks, when the thermal insulation is average, $\mathrm{K}=1.0-1.9$;

- For high-quality double-sided insulated wall, $\mathrm{K}=0.6-0.9$ when the thermal insulation is high.

To determine the amount of heat capacity, we take the following as initial data:

- Heated area, the internal area of the project 1-storey cottage - $120 \mathrm{~m}^{2}$;

- Room height - $2.8 \mathrm{~m}$; 
- The outdoor temperature in winter, $-20^{\circ} \mathrm{C}$;

- The required temperature in the room, 18 ${ }^{\circ} \mathrm{C}$;

- Difference between external and internal temperatures in winter, $\mathrm{T}=38^{\circ} \mathrm{C}$;

- K- diffusion coefficient (type of construction i depends on the insulation condition of the room), $K=1,0$.

If we put this information in the formula (1), $\mathrm{Q}_{\text {тн }}=\mathrm{V} * \mathrm{~T} * \mathrm{~K}, \mathrm{kcal} / \mathrm{hour}=120 * 2,8 * 38 * 1=12768$ $\mathrm{kcal} /$ hour.

If,

$$
1 \mathrm{~kW}=860 \mathrm{kcal} / \mathrm{hour}
$$

Given the relationship, we find the amount of $\mathrm{kW}$ of heat required:

$Q_{T H}=12768 / 860=14,8 \mathrm{~kW}$.

A number of collectors required to heat the building:

$$
N_{k}=Q_{\text {тн }} / Q_{k}=14,8 \mathrm{~kW} * 10^{3} / 1200=12 \text { pcs. }
$$

Evaluation of the cost-effectiveness of a combined heating system for heating a building. If the building is heated only by solar collectors, the current cost value will be the power consumption of the electric drive (one $50 \mathrm{~W}$ ) which is used to ensure the forced circulation of the forced heat carrier in the system.

If 12 solar collectors (each with a capacity of 1.2 $\mathrm{KWh}$ ) are installed from the Thermotech FP2O2 solar collector to heat the building, their electric drives will consume $0.6 \mathrm{kWh}$ of electricity per hour. The amount of electricity consumed during the heating season (182 days) is found as follows:

$$
P_{\text {elect }}=(24 * 182) * 0.6=2620.8 \mathrm{kWh}
$$

Electricity consumed during the heating season when the building is heated by an electric

heater

$Q=Q_{\text {тн }} *(24 * 182)=14,8 * 24 * 182=64646,4 k W h *$ hours (5)

The annual energy efficiency of solar collector used:

$C_{\text {col }}=Q-P_{\text {elect }}=64646,4-2620,8=62025,6 \mathrm{~kW} * \mathrm{~h}$

If we multiply the amount found by the tariff for $1 \mathrm{kWh}$ of electricity - 200 soums, the financial value of energy efficiency $62025.6 * 200=12405$ thousand soums. If the building is heated only by a heat pump, the amount of electricity consumed during the heating season ( 182 days) is found as follows:

$$
P_{\text {pump }}=(24 * 182) * 3,18=13890,24 k W * h
$$

The energy efficiency of the heat pump during the heating season:

$C_{\text {pump }}=Q \quad-P_{\text {pump }}=64646,4-13890,24=50756$, $16 \mathrm{kVt}$

If we multiply the amount found by the tariff for $1 \mathrm{kWh}$ of electricity - 290 soums, the 
financial value of energy efficiency - 50756.16 $*_{290}=14719$ thousand soums.

\section{REFERENCES}

1. Andersou B. (1982). Solnechnaya energiya» (pereod s angl. Pod. Redaktsiey Malevskogo Yu.N) Moscow «Stroizdat». (in Russian).

2. Diffi J.A. Beckman U.A. (1981). Thermal processes with the use of solar energy. $M$.

3. McWaig, D. (1981). The use of solar energy. M. "Energoizdat".

4. Rustam, A., \& Nasimbek, M. (2021). A New Method Of Soil Compaction By The Method Of Soil Loosening Wave. The American Journal of Engineering and Technology, 3(02), 6-16. 